\title{
E-Invigilation as a Means of Curbing Examination Malpractice in Colleges of Education in Nigeria
}

\author{
Ogunjobi, O. Pius, Adedara Rapheal Oluwadare, Ogunleye, W. Akinyemi
}

\begin{abstract}
The study examined e-invigilation as a means of curbing examination malpractice in colleges of education in Nigeria. The descriptive research design of a survey type was adopted in the study. The population comprises all students of College of Education, Ikere Ekiti. The sample of 250 students which were randomly selected using simple random sampling technique. A well structured questionnaire was used to collect data and was validated by some experts and reliability of the instrument was tested using the cronbach alpha coefficient and the result was found to have a reliability coefficient of 0.62 which indicated that the instrument was reliable to collect the necessary data for the study. Data collected was analyzed using mean, standard deviation and t-test was used to test the hypothesis formulated at 0.05 level of significant. The study concluded that e-invigilation will reduce examination malpractices and thereby restore the discipline among students in colleges of education since there was no significant difference in the mean responses of students on the impact of e-invigilation based on gender. The study recommended that CCTV should be installed to every lecture theatres where examination are been conducted so as to make e-invigilation effective.
\end{abstract}

Keywords: E-invigilation, Examination Malpractices, Students, CCTV.

\section{INTRODUCTION}

$\mathrm{E}$ teaching and learning process, and it is vital incentive to study like a method of receiving feedback as well as a standard in measuring overall efficacy of classroom instruction and placement. Examination generally remained a rigorous method of assessing students understanding, knowledge and ability academically in the field they have trained before certificate is awarded in educational establishment and this mainly designed to assess learners' academic progress and determine if they have met a standard of academic learning and knowledge. In the educational sector, examinations serve as a standard by which students' or candidates' knowledge and performance are systematically tested and assessed (1).

Manuscript received on May 18, 2021.

Revised Manuscript received on October 27, 2021.

Manuscript published on November 30, 2021.

*Correspondence Author

Ogunjobi, O. Pius*, Department of Agricultural Science Education, College of Education, Ikere Ekiti, Ekiti State, Nigeria. ogunjobi.olanrewaju@coeikere.edu.ng

Adedara Rapheal Oluwadare, Department of Computer Science Education, College of Education, Ikere Ekiti, Ekiti State, Nigeria. Email: adedaraoluwadare@gmail.com

Ogunleye, W. Akinyemi, Department of Vocational and Technical Education, Faculty of Education, Ekiti State University, Ado Ekiti. Email: wumiakinyemi@gmail.com

(C) The Authors. Published by Blue Eyes Intelligence Engineering and Sciences Publication (BEIESP). This is an open access article under the CC BY-NC-ND license (http://creativecommons.org/licenses/by-nc-nd/4.0/)
In education sector, "teaching and learning become more effective when the students are subjected to an examination process to determine the extent to which the students have assimilated the content of the instruction given and the teacher can also access himself from the performance of the students because the outcome of examinations goes a long way to determine whether the objectives of the academic process are being met or not"(2). Because of the importance of examinations mostly in educational area and emphasis place on certificate as only means of employment or advancement from a level to another, learners become ever more anxious to obtain certificates by any possible means, resulting in examination malpractices (Anwanbor, in 3). Examination malpractice according to Usman in (4) is "cheating in the examination or any intention to benefit or give undue advantage to oneself or another by deceit or fraud, before, during and after examination". This is in line with (5) that examination malpractice is the act of disregarding the rules and guidelines by a candidate or their representatives previously, during and after assessment to enjoy unnecessary benefits, such exercise give candidate undeserved benefit and decrease the dependability of their marks and scores if not caught or sanctioned. Ojerinde in (6) observed that "examination malpractice is already becoming a culture in the Nigerian educational scene, this is because the ugly face of examination malpractice is been acknowledged by most students". It is against this backdrop, the study investigates e-invigilation as a means of curbing examination malpractice in the Nigerian colleges of education.

\section{STATEMENT OF THE PROBLEM}

This issue has developed a bound crisis situation in the educational sector because malpractices in examinations have became so common that nearly everyone is concerned about the quality of graduates from Nigeria's higher education system, except those who commit examination malpractices. Ogum, in (7) argued that there is public concern about the low quality of education in Nigeria since the reputation of Nigerian education has been severely tainted as a result of examination cheating that characterizes the country's institutions of learning. The community is thusly losing trust in the certificates issued by educational institutions. In order to reduce the calamity of examination malpractice and because examination is very significant to students' success and everyone wants to pass examination, there is need for e-invigilation to allow every candidates to operate in the same and comparable favourable environment.

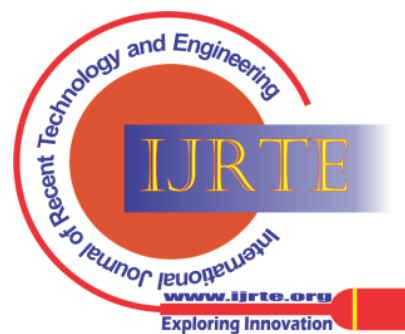


E- Invigilation according to (8) can be regarded as far off controlled terminal that are connected with the primary servers of an establishment and is useful in controlling both disconnected and online invigilation of examination in this way lessening the examination malpractice among the students. Therefore, study set to investigate e-invigilation as a means of curbing examination malpractice in the Nigerian colleges of education.

\section{PURPOSE OF THE STUDY}

The main purpose of this study was to investigate einvigilation as a means of curbing examination malpractice in the Nigerian Colleges of Education, a study of College of Education Ikere Ekiti.

Specifically, the study:

1. examine the impact of E-invigilation in the reduction of examination malpractice among students

\section{Research Question}

The following research question was answered.

1. What are the impacts of E-invigilation in the reduction of examination malpractice among students?

\section{Research Hypothesis}

The following research hypothesis was formulated.

1. There is no significant difference in the mean responses of students on the impact of E-invigilation in the reduction of examination malpractice based on gender

\section{LITERATURE REVIEW}

\section{Examination Malpractices}

Examination malpractice encompasses any illegal and dishonest acts that certain examination students participate in prior to during and after an examination (Onuka, and Durowoju, cited by (9). Examination malpractice according to (10) It is an illegal activity conducted for personal gain by any person in a position of trust and responsibility in the bureaucracy of a spoken or written test of understanding, competence, skills, or competence, and an infringement of laws and rules for selfish interests by all the parties involved in the administration of a spoken or written test of knowledge, skills, or ability. Examination malpractice takes different forms and dimensions. The following are the ways in which students used to cheat in examination:

1. Taking in of unfamiliar papers into the assessment centre (Curran, Middleton and Doherty, 2011).

2. Sending data by specialist or machineries from outside to applicant in the Examination centre.

3. Foreknowledge of assessment questions.

4. Cheating on a large scale with the participation of school authorities, competitors, and evaluation officials.

5. Candidates' insults/assaults supervisor/inspectors

6. Various examples include having two distinct handwritings on a candidate's script and using unsigned scripts, etc (5) (11).
All these activities completely contradict the aim of examination, which is to measure students' knowledge, and thus impedes the evaluation of students' actual knowledge. Even fight corruption would be futile if examination misconduct persists in our educational system. (12). "As future leaders, who have been equipped through a school system characterized by academic fraud and dishonesty, will certainly manifest this fraudulent behaviour in any organization they may found themselves" (12).

Examination malpractices result in irreparable credibility loss. A country's international reputation suffers when it becomes known for examination malpractices. The consequence is that documents or certificates issued by such country will be viewed with mistrust, as is now the situation in Nigeria. In terms of international educational collaboration, such country's educational institutions are all but extinct (13).

Through examinations malpractice some student could be enticed to participate in additional types of misconduct, such as prostitution and/or attempted robbery. Students who do not have enough money to resolve or pay for their grades may resort to human trafficking, whilst males may resort to pilfering or armed robbery to try and generate money to pay for their grades [14], [15] [16].

Other effects of examination malpractice includes discouragement of students from hard work, low productivity and poor job performances, bribery, corruption, and certificate racketeering, [12]. It is therefore germane to examine the techniques of curbing the menace in order to upgrade the credibility of certificates awarded in schools and generally enhance qualitative education.

\section{E-INVIGILATION}

Because of the high rate of examination malpractices among students in Nigeria, many measures have been taken to eradicate the menace such as online registration that was introduced in 2005 to checkmate rate of pantomime through electronically caught photos, issuance of produce confirmation endorsements with high evaluation security highlights like watermarks, 3D images, and duplicate verification marks-production manufactured outcomes effectively detectible as well as E-confirmation and verification of results [5].

Despite all the measures taken, the problem is still rampant among students. Hence, e-invigilation seen to be the solution to curb examination malpractices because there is no uncertainty that cutting edge life is overwhelmed by innovation and since there is widespread acknowledgment of the need to utilize Information and Communication Technology (ICT) E-Invigilation in education as we enter the period of Globalization, [17], [8].

Reference [10] found that if e-invigilation is effective, cases of examination malpractices if not avoided will be drastically minimized whereas if the invigilation is slack and very ineffective cases of examination malpractice will be on the increase and thereby become the order of the day which we are experiencing today.

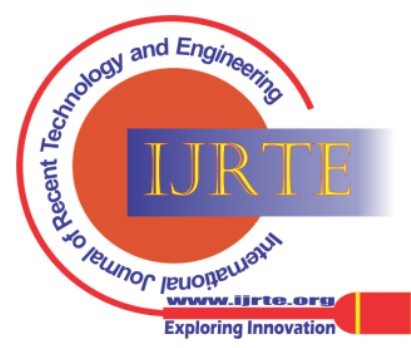


This investigation set underscores on the installation of CCTV camera for surveillance in examination hall of every tertiary institution in Nigeria because the presence of CCTV cameras alone is equipped for terrifying potential negligence up-and-comers, since they are very much aware of being watched, with the conceivable outcomes of recorded clasps being documented as proof of misbehavior against such student [Curran in 8]. Another method as indicated by Curran in [8] believed that the utilization of air terminal metal indicators is equipped for debilitating candidates who attempt to sneak in mouthpieces and earpieces since up-andcomer with such gadgets stroll through the metal identifier, it creates a blare as an indication of the presence of metal gadgets. The E-invigilation is acceptable as per Percival et al in [8] in light of the fact that it serves to checking all organizations for traffic from the computers in the homeroom, recording it and simultaneously recognizing progressively any movement that is suspected to disregard the guidelines set up for the examination and alert the invigilator.

\section{Basic Facilities needed for CCTV Installation in Examination hall}

The following are the major materials and equipments of CCTV installation

$\begin{array}{ll}\text { - } & \text { CCTV camera } \\ \text { - } & \text { Internet connection } \\ \text { - } & 45 \text { inch LCD monitor } \\ \text { - } & \text { DVR and wiring cable } \\ \text { - } & \text { BNC video input } \\ \text { - } & \text { TV with composite video input } \\ \text { - } & \text { Coax cables, flat cables }\end{array}$

- $\quad$ CCTV camera

- $\quad$ Internet connection

- 45 inch LCD monitor

- $\quad$ DVR and wiring cable

Hard disk

Table 1: Impacts of E-invigilation in the reduction of examination malpractices

\begin{tabular}{|c|c|c|c|c|}
\hline $\mathbf{S} / \mathbf{N}$ & ITEM & Mean & St.D & Remarks \\
\hline 1 & E-invigilation scare me to involves in examination malpractices & 3.52 & 0.88 & Agreed \\
\hline 2 & E-invigilation is good in tertiary institutions & 3.52 & 0.50 & Agreed \\
\hline 3 & $\begin{array}{l}\text { E-invigilation will expose student involve in examination malpractices than human } \\
\text { invigilation }\end{array}$ & 3.66 & 0.63 & Agreed \\
\hline 4 & $\begin{array}{l}\text { Through e-invigilation there will be enough evidence to judge student caught in } \\
\text { examination malpractices }\end{array}$ & 3.51 & 0.64 & Agreed \\
\hline 5 & $\begin{array}{l}\text { Availability of E-invigilation will encourage students to be more serious to read their } \\
\text { book }\end{array}$ & 3.04 & 0.85 & Agreed \\
\hline 6 & E-invigilation will trigger students to make use of School libraries adequately & 2.91 & 0.74 & Agreed \\
\hline 7 & E-invigilation will helps to restore the educational value in tertiary institution & 3.32 & 0.74 & Agreed \\
\hline 8 & $\begin{array}{l}\text { E-invigilation will encourage students to work hard in order to perform better in their } \\
\text { examination }\end{array}$ & 3.40 & 0.64 & Agreed \\
\hline 9 & $\begin{array}{l}\text { E-invigilation will reduces miscellaneous cases like using of unsigned scripts by the } \\
\text { students }\end{array}$ & 2.86 & 1.05 & Agreed \\
\hline 10 & E-invigilation will improves quality of education in Nigeria & 3.16 & 1.13 & Agreed \\
\hline 11 & Fight against corruption in educational system can be achieved through E-invigilation & 3.34 & 0.93 & Agreed \\
\hline 12 & E-invigilation will build self-confidence among students in tertiary institution & 3.31 & 0.46 & Agreed \\
\hline 13 & $\begin{array}{l}\text { E-invigilation will promote high level of } \\
\text { discipline in tertiary institution in Nigeria }\end{array}$ & 3.20 & 0.88 & Agreed \\
\hline 14 & $\begin{array}{l}\text { E-invigilation will reduce fake drug manufacturing emanating from examination } \\
\text { malpractice }\end{array}$ & 2.89 & 1.07 & Agreed \\
\hline 15 & E-invigilation will increase my knowledge about ICT & 3.32 & 1.01 & Agreed \\
\hline & Grand mean & 3.26 & & Agreed \\
\hline
\end{tabular}

\section{$\bar{X} \leq 2.50$ indicate Agreed otherwise "Disagreed"}

- $\quad$ RJ11, Cable cutter stripper

- $\quad$ RCA and F connectors

- AHD test monitor

- CAT-5 cable

- $\quad$ PTZ tester

- $\quad$ IP cameras system

\section{METHODOLOGY}

The research design used for the study was descriptive design of a survey type. The population of the study covers all students of College of Education, Ikere Ekiti. The sample consists of 250 who were selected using simple random sampling technique to complete questionnaires on einvigilation as a means of curbing examination malpractice in the Nigerian Colleges of Education. A well structured questionnaire was used to collect data for the study and the instrument was validated by some experts and the reliability of the instrument was determined through a pilot-test conducted by the researcher on the instrument and reliability co-efficient of 0.62 using the cronbach alpha coefficient measurement which indicated that the instrument was reliable to collect the necessary data for the study. Data collected was analyzed using mean, standard deviation and t-test was used to test the hypothesis formulated at 0.05 level of significant.

\section{RESULTS}

Descriptive Analysis

Research Question 1: What are the impacts of Einvigilation in the reduction of examination malpractices? 
The result presented in table 1 revealed the response of students on the impacts of E-invigilation in reducing examination malpractices. The mean values in the table are greater than 2.50 which indicated that majority of the respondents agreed with all statements in item 1 - 15 that Einvigilation will reduce students' involvement in examination malpractices (3.52), E- invigilation is good in tertiary institutions (3.52), E-invigilation will expose student involve in examination malpractices than human invigilation (3.66) Enough evidence to judge student caught in examination malpractices will be available through einvigilation (3.51), Availability of E-invigilation make students to be more committed to read their book (3.04), it will also trigger students to make use of School libraries will be restored (3.32), E-invigilation encourage students to work hard in order to perform better in their examination (3.40), installation of E-invigilation devices will reduces miscellaneous cases like using of unsigned scripts by the students (2.86), improves quality of education in Nigeria (3.16), fight against corruption in educational system would be achieved through E-invigilation (3.34), building selfconfidence among students in tertiary institution (3.31), promote high level of discipline in tertiary institution (3.20), it will reduce fake drug manufacturing emanating from examination malpractice (2.89) and it will increase students knowledge about ICT (3.32). The grand mean in the table is also greater than 2.50. This further justified the claim that majority of the respondents agreed with all the impacts of einvigilation on examination malpractices.

\section{Test of Hypothesis}

Ho1: There is no significant difference in the mean responses of students on the impact of E-invigilation based on gender

Table 2: t-test analysis shown the mean responses of students on the impact of E-invigilation based on gender

\begin{tabular}{|c|c|c|c|c|c|c|}
\hline Variables & $\mathbf{N}$ & Mean & $\begin{array}{c}\text { Standard } \\
\text { Deviation }\end{array}$ & Df & t-cal & t-tab \\
\hline Male & 107 & 48.60 & 2.39 & & & \\
\cline { 1 - 4 } Female & 143 & 49.33 & 6.27 & 248 & 1.13 & 1.96 \\
\hline
\end{tabular}

$\mathbf{P}<0.05$ (Sig.)

The result of analysis in table 2 revealed that t-calculated (1.13) was lesser than t-table (1.96) at 0.05 level of significance. This led to the upheld of null hypothesis 1 , hence, there was no significant difference in the mean responses of students on the impact of E-invigilation based on gender.

\section{DISCUSSION OF FINDINGS}

The results of the findings revealed that e-invigilation have impacts on the examination malpractices among students in colleges of education such include; promote high level of discipline in tertiary institution, exposing student involve in examination malpractices than human invigilation, encourage students to read and work hard for them to obtain better grade in examination, also to achieve fighting against adequately (2.91), educational value in tertiary institution

corruption in educational system, This is in line with (10) who founded that if e-invigilation is effective, cases of examination malpractices if not eradicated will be drastically minimized.

\section{CONCLUSION AND RECOMMENDATIONS}

Based on the findings of this study, it was concluded that einvigilation will reduce examination malpractices and thereby restore the discipline among students in colleges of education in Nigeria. Also there was no significant difference in the mean responses of students on the impact of E-invigilation based on gender. Therefore, the study recommended that CCTV should be installed to every lecture theatres where examination are been conducted. In addition, all facilities such as electricity power supply, computers, and others should be adequately provided in order to facilitate the effective e-invigilation.

\section{ACKNOWLEDGMENTS}

The authors of this article warmly acknowledge TETFund for sponsoring this research. Also, the authors acknowledge the comments or suggestions provided by (Dr. Obasuyi, Economics Department, Bamidele Olumilua University of Education, Science and Technology Ikere Ekiti). Your contributions in this study are appreciated.

\section{REFERENCES}

1. M. U., Nnam, \& A. F. Inah, Empirical Investigation into the Causes, Forms and Consequences of Examination Malpractice in Nigerian Institutions of Higher Learning. International Journal of Novel Research in Humanity and Social Sciences, 2015, 2(1), pp 52 - 62

2. F. Omemu, Causes of examination malpractice in Nigeria schools. British Journal of Education, 2015, 3(7) PP 34-41

3. O. O., Akanni, \& B. Odofin, Reducing Examination Malpractices in Nigerian Schools through Effective Continuous Assessment (C.A.) Techniques as an Alternative to One-Shot Examination in Osun State, Nigeria. American Journal of Educational Research, 2015, 2(1) pp 91 $-101$

4. S. O. Emaikwu, The Influence of Examination Malpractice on the Measurement of Students' Ability in Nigerian Universities. Journal of Research in Education and Society, 2012, 3 (1) pp 12-21

5. I. Uwadiae, \& P. Uduah. Impact of Information and Communication Technology on Examination Malpractice at the West African Senior Secondary Certificate Examinations in Nigeria. West African Examination Council Publications 2012, pp

6. S. J. Anzene, Trends in Examination Malpractice in Nigerian Educational System and its Effects on the Socio-Economic Development of Nigeria. Asian Journal of Humanities and Social Sciences, 2014, 2(3) pp $1-8$

7. S. O. Emaikwu, Assessing the relative effectiveness of three teaching methods in the measurement of student' achievement in mathematics. Journal of Emerging Trends in Educational Research and Policy Studies (JETERAPS). 2012, 3(4) pp 479-486

8. O.O. Fayomi, L. Amodu, C. K. Ayo, O. R. Idowu, \& F. O. Iyoha. "E Invigilation: Panacea to Examination Malpractice in Nigeria." Proceedings of ICERI2015 Conference 16th-18th November 2015, Seville, Spain 2016, pp 2849-2858.

9. O. Akintunde, \& G. S. Musa. "Environmental Insecurity and the Nigerian Child's Learning: Coping Strategies." Asia pacific multidisciplinary research 2016. 4 (1) pp 13-17

10. A. O. Alabi, Effective Invigilation as a Panacea for Examination Malpractices among Students of Tertiary Institutions in Nigeria. Global Journal of Human-Social Science: A Arts \& Humanities Psychology 2014, 14 (2), PP 59-62

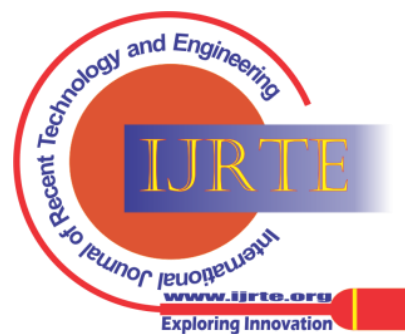


11. K, Curran, G. Middleton, \& C. Doherty. "Cheating in exams with technology." International Journal of Cyber Ethics in Education (IJCEE) 1, no. 2, 2011, PP 54-62.

12. C.O, Onyibe, U., Uma, \& I. Emmanuel, Examination Malpractice in Nigeria: Causes and Effects on National Development. Journal of Education and Practice 2015, 6 (26), 12-17

13. B. O. Jimoh, Examination Malpractice in Secondary Schools in Nigeria: What sustains it? European Journal of Educational Studies, 2009, 1(3), PP 101 - 108

14. G. Adewale, Examination Malpractice: A Stigma on School Effectiveness in Nigeria. Https://www.unilorin.edu.ng 2014.

15. M. Uzoccukwu, Examination Malpractice and Causes. http://uzochuk umike. Hubpages. Com June 16, 2015

16. S.U Oko \& R.I. Adie Examination Malpractice: Causes, Effects and Possible Ways of Curbing the Menace. A Study of Cross River University of Technology. International Journal of Managerial Studies and Research (IJMSR) 2016, 4(1), 59-65

17. S. E. Aduwa-Ogrebaen, \& O.S. Iyamu, Using Information and Communication Technology in Secondary Schools in Nigeria: Problems and prospects: Educational Technology and Society, 2015, 8 (1), 104-112.

\section{ABOUT THE AUTHORS}

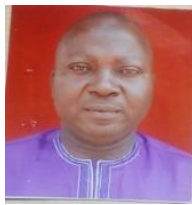

Raphael Oluwadare Adedara is currently a Senior Lecturer at the Department of Computer Science Education, School of Sciences, College of Education, Ikere Ekiti, Nigeria. He obtained his Bachelor of Science in Computer Science and Master of Science in Computer and Information Science from Ekiti State University, Nigeria (EKSU) and Lead City University (LCU) in 2005 and 2017 respectively. He is currently, a Ph.D. student at University of Strathclyde, Glasgow, UK. He is a member of the IEEE and many other international computing societies. His fields of interest are: Web and Mobile Applications Development, Utilization and Evaluation, Data Science, Networking and Health Information Technology. He has published several papers in International, National journals and conferences.

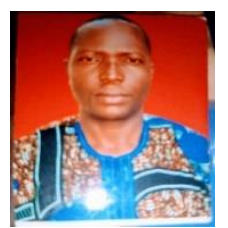

Ogunjobi, Olanrewaju Pius with the Orcid number 0000000255445555 is currently a Principal Agricultura Superintendent I at the Department of Agricultural Education, School of Vocational and Technical Education, College of Education, Ikere Ekiti, Nigeria. He obtained his Higher National Diploma in Agricultural Engineering specializing in Soil \& Wate Resources \& Conservation Engineering in 1999 and Bachelor of Science in Education in Agricultural Education in 2013 from Federal Polytechnic, Ado Ekiti and University of Nigeria, Nsukka respectively. He is currently on his MSc.(Ed) in Agricultural Education programme at Ekiti State University, Ado Ekiti, Nigeria. He is a member of International Vocational Education and Training Association and many other international societies. His fields of interest are: Vocational Agricultural Education, Information Communication Technology, Agricultural Technology, Entrepreneurship in Agricultural Education and Agribusiness among others. He has published several papers in local and International journals.

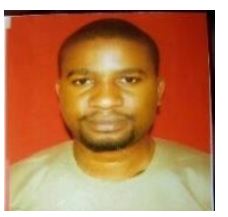

Ogunleye Wumi Akinyemi obtained his Bachelor of Science in Accounting Education in 2015 from University of Nigeria, Nsukka. The author is a post graduate student at Department of Vocational and Technical Education, (Business Education Accounting option) Ekiti State University, Ado Ekiti, Ekiti State, Nigeria. Currently, He is working as a data analyst and he has many publications related to Accounting Education, Entrepreneurship, and Information Communication and Technology published in reputable international and national journals. His research interest includes Accounting, Education and Information Communication and Technology. The ongoing research is on the availability and utilization of internet facility, accounting software for teaching and learning in secondary schools.

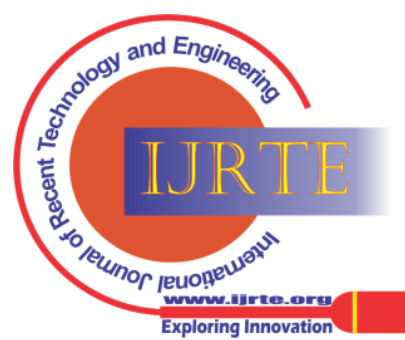

